\title{
Preliminary results for genetic transformation of shoot tip of Eucalyptus saligna Sm. via Agrobacterium tumefaciens
}

\author{
André Luís Lopes da Silva ${ }^{1 *}$, Yohana de Oliveira ${ }^{2}$, Jefferson da Luz Costa ${ }^{1}$, Clarissa de \\ Souza Mudry ${ }^{2}$, Marcia Procopiuk ${ }^{2}$, Gessiel Newton Scheidt ${ }^{3}$ and Gilvano Ebling Brondani ${ }^{2}$ \\ ${ }^{1}$ Departamento de Engenharia de Bioprocessos e Biotecnologia; Universidade Federal do Paraná; 81531-970; \\ Curitiba - PR - Brasil. ${ }^{2}$ Departamento de Fitotecnia e Fitosanitarismo; Universidade Federal do Paraná; 80035- \\ 050; Curitiba - PR - Brasil. ${ }^{3}$ Departamento de Ciências Agrárias e Tecnológicas; Universidade Federal do \\ Tocantins; 77402-970; Gurupi - TO - Brasil.
}

\begin{abstract}
The regeneration of transgenic plants of Eucalypt is the largest difficulty for the genetic transformation of this genus; in addition a low rate of transformed plants is reached. The aim of this research was to evaluate acetosyringone (3',5'-Dimethoxy-4'-hydroxyacetophenone) on the co-culture medium during genetic transformation of shoot tips of Eucalyptus saligna via Agrobacterium tumefaciens and to promote the explants selection supposedly transformed. Shoot tip from multiple shoots was used as explants. These explants were pre-cultured during two days before the transformation. Strain EHA105 of A. tumefaciens harboring the plasmid pBI121 was used. The treatments were: 0 and $100 \mu \mathrm{M}$ acetosyringone added to the co-culture, after co-culture the explants were cultured in multiplication medium supplemented with $250 \mathrm{mg} . \mathrm{L}^{-1}$ Cefotaxime ${ }^{\circledR}$ and each sub-culture the kanamycin levels were increased from 50 to $150 \mathrm{mg} . \mathrm{L}^{-1}$. The transient expression of the uidA gene in shoot tips was evaluated after the end of the co-culture (fifth day) and after seven days of culture on medium containing kanamycin. The presence of $100 \mu \mathrm{M}$ acetosyringone at the co-culture of shoot tips of Eucalyptus saligna promoted higher transient expression of the uidA gene and retards toxic effects caused by kanamycin.
\end{abstract}

Key words: Strain EHA105, GUS gene, Eucalypt, $\beta$-glucuronidase

\section{INTRODUCTION}

Eucalyptus saligna is relatively adapted in all Brazilian territory (Ferraz and Coutinho, 1984; Corrêa et al., 2005), nevertheless, this species is no much tolerant to cold (Le Roux and Van Staden, 1991), and it is susceptible to frost (Ferraz and Coutinho, 1984). The largest restriction to eucalypt culture in the south of Brazil is due to cold and to the incidence of frosts (Silva et al., 2009, Brondani et al., 2010a; Brondani et al., 2010b). Frost is too severe that eucalypt trees show since burned tip until dead of the aerial part (Selle and Vuaden, 2008). However, genetic transformation can overcome susceptibility to biotic and abiotic stresses (Silva et al., 2010) what can allow the adaptation of this species even in cold climates. Although the risks pointed in the culture of the genetically modified plants, there are several methodologies that guarantee the safe use of these plants (Silva et al., 2007).

Genetic transformation protocol for E. saligna was already established using leaf explants (Dibax, 2007, Dibax et al., 2010). However, leaf explants are arduous to manipulate due to small size, besides this explants has a great ability to oxidize and relative capacity to regenerate. Oxidation can be more elevated due to TDZ (Thidiazuron) presence (Vatankhah et al., 2010), whereas TDZ stimulates ethylene production that induces senescence (Karavaiko et al., 2004). On the other hand, a genetic transformation protocol using shoot tip had the advantages of: (1) explants with high regenerative ability (multiplication phase), (2) difficulty to oxidize at begin (larger tendency in old cultures, usually more than 20 days of in vitro culture), (3) larger explants $(5 \mathrm{~mm})$ which

$\overline{\text { Author for correspondence: clonageinvitro@yahoo.com.br }}$ 
results in more easiness to manipulate and (4) do not use TDZ.

The aim of this research was to evaluate acetosyringone (3',5'-Dimethoxy-4'hydroxyacetophenone) on the co-culture medium during genetic transformation of shoot tips of Eucalyptus saligna via Agrobacterium tumefaciens and to promote the explants selection supposedly transformed.

\section{MATERIAL AND METHODS \\ Source of explants}

Multiple shoots of Eucalyptus saligna Sm. originated from cotyledonary explants and multiplicated according to the protocol established by Dibax (2007) and Dibax et al. (2010) were explant donors. Light intensity during in vitro multiplication was $25 \mu \mathrm{M} \mathrm{m}^{-2} \mathrm{~s}^{-1}$. Shoot tips ( $5 \mathrm{~mm}$ heigth and without lateral shoots) were used as explants to genetic transformation. Before of the genetic transformation was carried out a preculture of two days. The pre-culture consisted of the maintenance of the explants cultured on MS medium (Murashige and Skoog, 1962) supplemented with 30 g.L $\mathrm{L}^{-1}$ sucrose, $1.11 \mu \mathrm{M}$ BAP (6-benzylaminopurine) and solidified with 7 g. $\mathrm{L}^{-1}$ agar (multiplication medium). Light intensity during pre-culture was $5 \mu \mathrm{M} \mathrm{m}^{-2} \mathrm{~s}^{-1}$.

\section{Strain, plasmid and conditions of culture and co-culture of Agrobacterium tumefaciens}

The strain EHA105 (Hood et al., 1993) of A. tumefaciens harboring the plasmid pBI121 (Zhang et al., 1995) were used. The plasmid pBI contain the gene of interest, P5CSF129A which is the mutant gene of P5CS from Vigna aconitifora (Hong et al., 2000). This gene is under transcriptional control on the $35 \mathrm{~S}$-CaMV promoter (from cauliflower mosaic virus). This gene is placed among the promoter and the region NOS3', this construct was inserted at the site EcoRI of vector $\mathrm{pBI} 121$. This vector also contains the $n p t I I$ and uidA (GUS) genes, controlled to the promoters, NOS-P (nopaline synthase) and $35 S$, respectively, both containing the terminator NOS3' (Fig. 1).

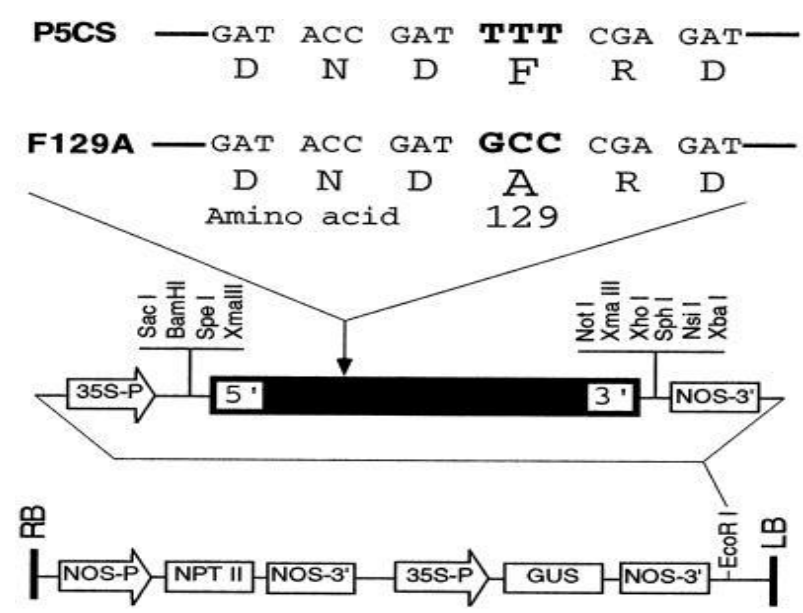

Figure 1- T-region of the pBI121 plasmid used in $E$. saligna genetic transformation. P5CSF129A is a mutant gene construction (Zhang et al., 1995) originated from P5CS - V. aconitifolia gene, NPTII - neomycin phosphotransferase II gene, GUS - reporter gene, encodes $\beta$-glucuronidase (also called uidA gene), NOS$P$ - nopaline synthase promoter gene, 35S-P cauliflower mosaic virus (CaMV) promoter, NOS-3' A. tumefaciens nopaline synthase terminator, RB - TDNA right border, LB - T-DNA left border.

The strain EHA105 was cultured on solid YEB medium (15 g.L. $\mathrm{L}^{-1}$ agar) (Vervliet et al., 1975) and supplemented with $50 \mathrm{mg} . \mathrm{L}^{-1}$ kanamycin and 25 mg. $\mathrm{L}^{-1}$ Riphampicin at $28^{\circ} \mathrm{C}$ during $48 \mathrm{~h}$ (in dark) to obtaining of isolated colonies. Isolated colonies ( 2 to 4 colonies) of EHA105 were collected with the use of the sterile toothpicks and cultured in 5 $\mathrm{mL}$ of liquid YEB medium added with $50 \mathrm{mg} . \mathrm{L}^{-1}$ kanamycin and $25 \mathrm{mg} . \mathrm{L}^{-1}$ Riphampicin at $28^{\circ} \mathrm{C}$ in dark during $24 \mathrm{~h}$ in orbital shaker $(150 \mathrm{rpm})$. The absorbance (OD = optical density) of the bacterial suspension was determined with spectrophotometer, the culture was adjusted with dilution in YEB medium supplemented as described above, dilution were accomplished until the obtaining of $\mathrm{OD}_{600 \mathrm{~nm}}=0.85$. The bacterial suspension $(1 \mathrm{~mL})$ was transferred to a sterile tube. This cell suspension was centrifuged at $5.000 \mathrm{rpm}$ during $10 \mathrm{~min}$, the supernatant was discarded and the cells were resuspended in $1 \mathrm{~mL}$ liquid culture medium, which is MS/2 (half-strength) supplemented with 30 g. $\mathrm{L}^{-1}$ sucrose and $\mathrm{pH}$ was adjusted to 5.8. It was used 10 shoot tip per sterile tube to Agrobacterium infection. All antibiotics used in this research were sterilized by microfiltration $(0.22 \mu \mathrm{m})$. Acetosyringone was placed at the culture medium after autoclaving. 
Acetosyringone was not microfiltered and autoclaved because was diluted in DMSO (Dimethyl sulfoxide).

Sterile tubes containing shoot tips and bacterial solutions was incubated during $30 \mathrm{~min}$ at $25^{\circ} \mathrm{C}$ (in dark) under $150 \mathrm{rpm}$ in an orbital shaker. Soon after, these explants were dried in a sterile filter paper and co-cultured on medium supplemented with $100 \mu \mathrm{M}$ Acetosyringone or Acetosyringonefree. Basal medium was MS medium supplemented with 30 g. $\mathrm{L}^{-1}$ sucrose, $1.11 \mu \mathrm{M}$ BAP and solidified with 7 g.L $\mathrm{L}^{-1}$ agar (multiplication medium). These explants were cultured at light intensity of $5 \mu \mathrm{M} \mathrm{m}^{-2} \mathrm{~s}^{-1}$. Co-cultured consisted of five days. At the end of the co-culture, the explants was subcultured to same basal medium free of acetosyringone and supplemented with $250 \mathrm{mg} . \mathrm{L}^{-1}$ Cefotaxime $^{\circledR}$ and $50 \mathrm{mg} \cdot \mathrm{L}^{-1}$ kanamycin to elimination of Agrobacterium tumefaciens and selection of cells transformed. After 14 days, these explants were subculture to the same medium, nevertheless with $75 \mathrm{mg} . \mathrm{L}^{-1}$ kanamycin. Each 28 days the explants were subcultured to the same medium, however kanamycin was increased each subcultured to $100,125,150 \mathrm{mg} . \mathrm{L}^{-1}$. At the sixth subculture after co-culture, the kanamycin was maintained to $150 \mathrm{mg} \cdot \mathrm{L}^{-1}$. The survival percentage and shoot number were evaluated at the end of each subculture.

\section{Histochemical assay of the $\beta$-glucuronidase}

The transient expression of the uidA gene in shoot tips was evaluated after the end of the co-culture (fifth day) and after seven days of culture on medium containing kanamycin. The expression of uidA gene was accomplished by histochemical detection of $\beta$-glucuronidase activity according Jefferson et al. (1987). The explants were placed at sterile tubes $(2 \mathrm{~mL})$ and covered by X-Gluc (5bromo-4-chloro-3-indolyl- $\beta$-D-glucuronic acid). After 16 hours at $37{ }^{\circ} \mathrm{C}$, it was made the X-Gluc removal and the samples were washed three times in ethyl alcohol $70 \%$ for chlorophyll removal. The samples were stored in ethyl alcohol $70 \%$, until be analyzed in stereomicroscope (Fig. 2).

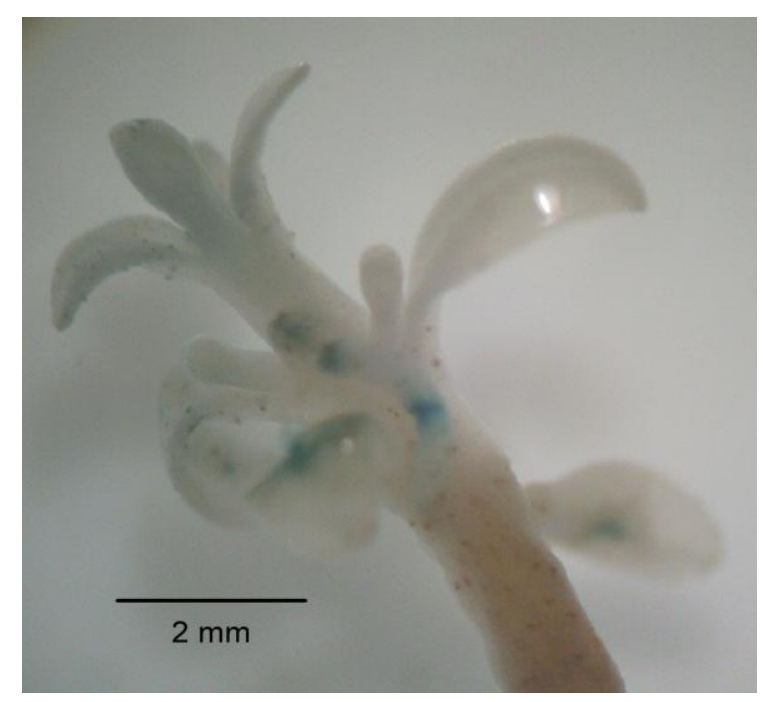

Figure 2- Shoot tip of Eucalyptus saligna with transient expression of uidA gene at the end of the co-culture (5 days) on the presence of $100 \mu \mathrm{M}$ Acetosyringone.

\section{Culture conditions and statistical analysis}

All media had their $\mathrm{pH}$ adjusted to 5.8, with exception bacteria media which had their $\mathrm{pH}$ adjusted to 7.5. All media were autoclaved at 1 atm and $121{ }^{\circ} \mathrm{C}$ for $20 \mathrm{~min}$. The plant cultures were kept at $25 \pm 2{ }^{\circ} \mathrm{C}$ with a $16 \mathrm{~h}$ photoperiod. The experimental design was completely randomized with five replicates of ten explants. The data was submitted in a homogeneity analysis for the Bartlett's method and, followed by analysis of variance (ANOVA) followed by Duncan's test, both at a $\mathrm{P}<0.05$. Variables from counting were transformed to $\sqrt{x+0.5}$ and variables from percentage were transformed to $\arcsin \sqrt{x / 100}$. All statistical analyses were done following the procedures of the software GENES (Cruz, 2001).

\section{RESULTS AND DISCUSSION}

Shoot tips presented similar transient expression of $G U S$ gene for number of the areas per explant at the end of the co-culture and at the seventh day on culture in kanamycin. However, some differences can be observed for number of the areas with expression per leaf; shoot tips co-cultured at the acetosyringone-free showed lower values in both evaluations. At the seventh day on culture in kanamycin, shoot tips co-cultured at the acetosyringone-free had $80 \%$ of explants with transient expression compared to $100 \%$ obtained by shoot tips co-culture at $100 \mu \mathrm{M}$ acetosyringone (Table 1). 
Table 1. Transient expression of uidA gene in shoot tip of Eucalyptus saligna at end of co-culture and after seven days cultured on medium with kanamycin. Percentage of the explants with transient expression of uidA gene (GUS \%), number of the areas with transient expression of uidA gene (NA) and number of the areas with transient expression of uidA gene per leaf (AL).

\begin{tabular}{ccccc}
\hline Acetosyringone $(\boldsymbol{\mu M})$ & Evaluation & GUS \% & NA & AL \\
\hline 0 & End of co-culture & 100 & $2.6 \pm 1.1^{1}$ & $1.0 \pm 0$ \\
& After 7 days in Kan & 80 & $1.4 \pm 2.0$ & $0.6 \pm 0.5$ \\
100 & End of co-culture & 100 & $2.6 \pm 0.9$ & $1.2 \pm 0.4$ \\
& After 7 days in Kan & 100 & $1.4 \pm 0.5$ & $1.2 \pm 0.4$ \\
\hline
\end{tabular}

${ }^{1}$ Standard deviation of the mean

These results are discordant those observed during the genetic transformation of leaf explants of $E$. saligna, wherein $100 \%$ and $50 \%$ of the leaf explants presented transient expression of the uidA gene at the end of the co-culture and after seven days on culture with $50 \mathrm{mg} . \mathrm{L}^{-1}$ kanamycin and 500 mg. $L^{-1}$ cefotaxime, respectively (Dibax, 2007; Dibax et al., 2010).

The BAP growth regulator is widely used for in vitro multiplication of buds of Eucalyptus sp. (Brondani et al., 2009; Hung and Trueman, 2010). The presence of BAP in the co-culture medium can have been beneficial to increase the transient expression of the uidA gene, as observed in the genetic transformation of Arabidopsis thaliana in the presence of the growth regulators, which demonstrated positive effects (Akama et al., 1992; Graaff et al., 2001; Karavaiko et al., 2004; Walz et al., 2008).

The selection of transformed explants was not made immediately, at the 14 days of culture at 50 mg. $L^{-1}$ kanamycin, the explants continued multiplying, similar to that reported by Dutt et al. (2010). These results were according those found in Eucalyptus saligna cultured on kanamycin after 28 days; these explants produced ca. 2.6 shoots per explant (Silva et al., 2010). Even with the increase of the kanamycin level to the $75 \mathrm{mg} . \mathrm{L}^{-1}$ the explants continued multiplying (ca. 4.4 shoot per explant). Nevertheless, the shoot number begins to decrease with the increase of the kanamycin level to the $100 \mathrm{mg} . \mathrm{L}^{-1}$; and the survival percentage was not altered $(100 \%)$. However, at the end of the third subculture (70 days) the explants in both treatments presented some oxidation level. The often subcultures and the low light intensity can be aided to avoid explants oxidation. On the other hand, when leaf explants are transformed, the oxidation begins to occur soon after the excision from tissues (Dibax, 2007; Dibax et al., 2010).

At the fourth subculture (98 days at the presence of kanamycin), at the $125 \mathrm{mg} . \mathrm{L}^{-1}$ kanamycin the explants begin to die (Table 2). These treatments show statistical differences for shoot number and survival percentage (Table 2). The presence of 100 $\mu \mathrm{M}$ acetosyringone in co-cultured promoted higher shoot number and survival percentage at the fourth and fifth subculture (Table 2).

Table 2. Shoot number and survival percentage of shoot tip of Eucalyptus saligna transformed via Agrobacterium tumefaciens and co-cultured with 0 and $100 \mu \mathrm{M}$ acetosyringone cultured on multiplication medium with kanamycin.

\begin{tabular}{cccccc} 
& \multicolumn{4}{c}{ Acetosyringone $(\boldsymbol{\mu M})$} \\
\cline { 2 - 5 } & & $\mathbf{0}$ & $\mathbf{1 0 0}$ & $\mathbf{0}$ & $\mathbf{1 0 0}$ \\
\hline Kanamycin $\left(\mathbf{m g . L}^{-\mathbf{1}}\right)$ & Subculture time (days) & Shoot number & \multicolumn{2}{c}{ Survival (\%) } \\
\hline 50 & 14 & $2.4 \mathrm{a}^{1}$ & $2.9 \mathrm{a}$ & $100 \mathrm{a}$ & $100 \mathrm{a}$ \\
75 & 28 & $4.2 \mathrm{a}$ & $4.6 \mathrm{a}$ & $100 \mathrm{a}$ & $100 \mathrm{a}$ \\
100 & 28 & $3.6 \mathrm{a}$ & $4.4 \mathrm{a}$ & $100 \mathrm{a}$ & $100 \mathrm{a}$ \\
125 & 28 & $1.3 \mathrm{~b}$ & $2.5 \mathrm{a}$ & $39.2 \mathrm{~b}$ & $84.6 \mathrm{a}$ \\
150 & 28 & $1.0 \mathrm{~b}$ & $2.1 \mathrm{a}$ & $3.8 \mathrm{~b}$ & $33.5 \mathrm{a}$ \\
150 & 28 & $0 \mathrm{a}$ & $0 \mathrm{a}$ & $0 \mathrm{a}$ & $0 \mathrm{a}$ \\
\hline
\end{tabular}

${ }^{1}$ Means within a line for each parameter followed by the same lower case letter are not different at $\mathrm{P}<0.05$ by Duncan's test. 
At the end of the sixth subculture (154 days) the explants did not survived for both treatments $(0$ and $100 \mu \mathrm{M}$ acetosyringone). These results are according those found in E. saligna cultured at 50$150 \mathrm{mg} . \mathrm{L}^{-1}$ kanamycin, which at the 84 days the explants begin to die and all explants died in cultures above 140 days (Silva et al., 2010).

The protocol for genetic transformation of leaf explants of E. saligna, the explants are selected with $50 \mathrm{mg} . \mathrm{L}^{-1}$ kanamycin; and the selection occurs in ca. three months (Dibax, 2007; Dibax et al., 2010). Cotyledonary explants were selected with kanamycin in ca. three months too (Silva et al., 2010). The time of selection of shoot tips can be an inconvenient (five to six months), however, case the efficiency of the transformation rate was higher than other explants, this explants type can be a good alternative.

\section{CONCLUSIONS}

In conclusion, the presence of $100 \mu \mathrm{M}$ acetosyringone at the co-culture of shoot tips of Eucalyptus saligna promoted higher transient expression of the uidA gene and retards toxic effects caused by kanamycin.

\section{RESUMO}

A regeneração de plantas transgênicas de eucalipto representa a maior dificuldade para a transformação genética de plantas do gênero Eucalyptus, além de que taxas baixas de plantas transformadas são alcançadas. $\mathrm{O}$ objetivo desse trabalho foi avaliar a acetosiringona no meio de co-cultura durante a transformação genética de ápices caulinares de Eucalyptus saligna via Agrobacterium tumefaciens e promover a seleção dos supostos explantes transformados. Ápices caulinares originados de brotações múltiplas foram usados como explantes. Estes explantes foram pré-cultivados por dois dias antes da transformação. A linhagem EHA105 de $A$. tumefaciens contendo o plasmídeo pBI120 foi utilizada. Os tratamentos foram: 0 e $100 \mu \mathrm{M}$ de acetosiringona adicionada ao meio de co-cultura, após a co-cultura os explantes foram cultivados em meio de multiplicação suplementado com $250 \mathrm{mg} . \mathrm{L}^{-1}$ de cefotaxima e a cada subcultivo a concentração de canamicina foi aumentada, de 50 até 150 mg. $\mathrm{L}^{-1}$. A expressão transiente do gene uidA nos ápices caulinares foi avaliada no final da co-cultura e após sete dias em meio com canamicina (agente seletivo). A presença de 100 $\mu \mathrm{M}$ de acetosiringona no meio de co-cultura dos ápices caulinares de Eucalyptus saligna promoveu maior expressão transiente do gene uidA e retardou a ação tóxica causada pela canamicina.
Palavras-chave: Linhagem EHA105, gene GUS, Eucalipto, $\beta$-glucuronidase

\section{REFERENCES}

Akama, K.; Shiraishi, H.; Ohta, S.; Nakamura, K.; Okada, K.; Shimura, Y. (1992), Efficient transformation of Arabidopsis thaliana: comparison of the efficiencies with various organs, plant ecotypes and Agrobacterium strains. Plant Cell Reports, 12, 7-11.

Brondani, G. E.; Dutra, L. F.; Grossi, F.; Wendling, I.; Hornig, J. (2009), Establishment, multiplication and elongation in vitro of Eucalyptus benthamii Maiden \& Cambage $\mathrm{x}$ Eucalyptus dunnii Maiden. Revista Árvore, 33, 1119.

Brondani, G. E.; Wendling, I.; Grossi, F.; Dutra, L. F.; Araujo, M. A. (2010a), Eucalyptus benthamii $\times$ Eucalyptus dunnii minicutting technique: (ii) minicutting survival and rooting in relation to collection and seasons. Ciência Florestal, 20, 453465.

Brondani, G. E.; Wendling, I.; Grossi, F.; Dutra, L. F.; Araujo, M. A. (2010b), IBA application for rooting of Eucalyptus benthamii Maiden and Cambage $\mathrm{x}$ Eucalyptus dunnii Maiden minicuttings. Acta Scientiarum. Agronomy, 32, 667-674.

Corrêa, L. R.; Paim, D. C.; Schwambach, J.; FettNeto, A. G. (2005), Carbohydrates as regulatory factors on the rooting of Eucalyptus saligna Smith and Eucalyptus globulus Labill. Plant Growth Regulation, 45, 63-73.

Cruz, C. D. (2001), Programa Genes: versão Windows; aplicativo computacional em genética e estatística. Viçosa: UFV, Imprensa Universitária. p. 648 .

Dibax, R.; Deschamps, C.; Bespalhok Filho, J. C.; Vieira, L. G. E.; Molinari, H. B. C.; Campos M. K. F.; Quoirin, M. (2010), Organogenesis and Agrobacterium tumefaciens-mediated transformation of Eucalyptus saligna with P5CS gene. Biologia Plantarum, 54, 6-12.

Dibax, R. Transformação e expressão do gene PC5SF129-A em Eucalytus saligna. Tese 
(Doutorado em Agronomia) - Universidade Federal do Paraná, 2007.

Dutt, M.; Lee, D. H.; Grosser, J. W. (2010), Bifunctional selection-reporter systems for genetic transformation of citrus: mannose- and kanamycin-based systems. In Vitro Cellular \& Developmental Biology - Plant, 46, 467-476.

Ferraz, E. S. B. and Coutinho, A. R. (1984), Efeitos da geada na madeira de Eucalyptus saligna. IPEF, 28, 57-62.

Graaff, E. E.; Auer, C. A.; Hooykaas, P. J. J. (2001), Altered development of Arabidopsis thaliana carrying the Agrobacterium tumefaciens ipt gene is partially due to ethylene effects. Plant Growth Regulation, 34, 305-315.

Hong, Z.; Lakkineni, K.; Zhang, Z.; Verma, D. P. S. (2000), Removal of feedback inhibition of $\Delta^{1}$ Pyrroline-5-Carboxylate Synthetase results in increased Proline accumulation and protection of plants from osmotic stress. Plant Physiology, 122, 1129-1136.

Hood, E. E.; Gelvin, S. B.; Melchers, L. S.; Hoekema, A. (1993), New Agrobacterium helper plasmids for gene transfer to plants. Transgenic Resource, 2, 208-218.

Jefferson, R. A.; Kavanagh, T. A.; Bevan, M. W. (1987), GUS fusions beta-glucuronidase as a sensitive and versatile gene fusion marker in higher plants. EMBO Journal, 6, 3901-3907.

Karavaiko, N. N.; Selivankina, S. Y. U.; Kudryakova, N. V.; Maslova, G. G.; Burkhanova, E. A.; Zubkova, N. K.; Kulaeva, O. N. (2004), Is a $67-\mathrm{kD}$ cytokinin-binding protein from barley and Arabidopsis thaliana leaves involved in the leaf responses to phenylurea derivatives? (A Review). Russian Journal of Plant Physiology, 51, 790-797.

Le Roux, J. J. and Van Staden, J. (1991), Micropropagation of Eucalyptus species. Hortscience, 26, 199-200.

Murashige, T. and Skoog, F. (1962), Revised medium for rapid growth and bioassays with tobacco tissue culture. Physiologia Plantarum, 15, 473-497.

Selle, G. L. and Vuaden, E. (2008), Efeitos da geada sobre plantações de Eucalypus grandis. Caderno de Pesquisa Série Biologia, 20, 36-44.

Silva, A. L. L.; Walter, J. M.; Horbach, M. A.; Quoirin, M. (2007), Contenção do fluxo gênico de plantas geneticamente modificadas. Caderno de Pesquisa Série Biologia, 19, 18-26.

Silva, A. L. L.; Oliveira, Y.; Alcantara, G. B.; Santos, M.; Quoirin, M. (2009), Tolerância ao resfriamento e congelamento de folhas de eucalipto. Biociências, 17, 86-90.

Silva, A. L. L.; Oliveira, Y.; Costa, J. L.; Masetto, E.; Mudry, C. S.; Erasmo, E. A. L.; Scheidt, G. N. (2010), Shoot tip and cotyledon explants of Eucalyptus saligna $\mathrm{Sm}$. cultivated on different kanamycin levels. Journal of Biotechnology and Biodiversity, 1, 1-5.

Vatankhah, E.; Niknam, V.; Ebrahimzadeh, H. (2010), Activity of antioxidant enzyme during in vitro organogenesis in Crocus sativus. Biologia Plantarum, 54, 509-514.

Vervliet, G.; Holsters, M.; Teuchy, H.; Van Montagu, M.; Schell, J. (1975), Characterization of different plaque-forming and defective temperate phages in Agrobacterium strains. Journal of General Virology, 23, 33-48.

Walz, A.; Seidel. C.; Rusak, G.; Park, S.; Cohen, J. D.; Ludwig-Müller, J. (2008), Heterologous expression of IAP1, a seed protein from bean modified by indole-3-acetic acid, in Arabidopsis thaliana and Medicago truncatula. Planta, 227, 1047-1061.

Zhang, C-S.; Lu, Q.; Verma, D. P. S. (1995), Removal of feedback inhibition of $\Delta^{1}$-Pyrroline-5Carboxylate Synthetase, a bifunctional enzyme catalyzing the first two steps of proline biossynthesis in plants. Journal of Biological Chemistry, 270, 20491-20496. 